2020 TheoLogica

An International Journal for Philosophy of Religion and Philosophical Theology

S.I. CONCILIAR TRINITARIANISM

DOI: https://doi.org/10.14428/thl.v4i2.61363

\title{
Editorial: Conciliar Trinitarianism
}

BEAU BRANSON

Brescia University

beau.branson@brescia.edu

JOSEPH JEDWAB

Kutztown University

jedwab@kutztown.edu

SCOTT WILLIAMS

University of North Carolina, Asheville

swillia8@unca.edu

Much recent work in analytic theology concerned with Trinitarian doctrine has been limited both by: (1) a narrow focus on the apparent inconsistency of the doctrine and (2) little regard for the historical context in which the doctrine developed. This special issue represents an effort to overcome these limitations in two ways. First, following Timothy Pawl's definition of "Conciliar Christology," we define "Conciliar Trinitarianism" as the conjunction of claims about the Trinity in the first seven Ecumenical Councils. Rather than speculative attempts at reconciling, say, sentences taken from the Athanasian Creed, or the common parlance of contemporary, Western Christians, the papers in this issue all address specifically Conciliar Trinitarianism. Second, the special issue brings together both analytic philosophers and patristics scholars in a format in which, in several cases, a scholar from one field responds to a scholar from another. We hope that this will help to jump-start some further conversations between scholars in analytic philosophy and in patristics, as we believe both fields can benefit from a deeper mutual engagement in the study of Conciliar Trinitarianism.

Three papers happen to address the issue of whether, when conciliar texts speak generically of "God" they are referring to the Father (as in the Creedal phrase, "I believe in One God, the Father, Almighty..."), or to the Trinity as a whole. Declan O'Byrne ("On the Economic Focus of Conciliar Trinitarianism") argues that, although Conciliar Trinitarianism affirms the consubstantiality of the Father and Son, and the full divinity of the Spirit, it identifies the One God with the Father, not the Trinity. To that extent, certain modern manuals of theology mischaracterize Conciliar Trinitarianism. He also argues conciliar texts are not concerned with the 
metaphysics of the Trinity or the economy of salvation in isolation; rather claims about the immanent Trinity serve as grounds for claims about the economy of salvation.

Dale Tuggy ("When and How in the History of Theology Did the Triune God Replace the Father as the Only True God?") concedes that, strictly speaking, Conciliar Trinitarianism does not identify God with the Trinity, but argues this is nevertheless the best interpretation of council documents, when read in the context of later, non-ecumenical pronouncements and the theology of some of the councils' most prominent members, specifically Gregory of Nyssa and Gregory Nazianzen. Additionally, he argues this was a natural development by the Gregories of the theology they inherited from Basil, which took "homoousious" to mean "same kind of thing" (an Aristotelian secondary ousia) and was therefore irremediably tri-theistic. This required a shift from Basil's theology (which he argues was Unitarian) to a properly Trinitarian theology that takes "homoousious" to mean "same thing" (an Aristotelian primary ousia).

Andrew Radde-Gallwitz ("God is Not a Thing: A Response to Dale Tuggy") responds that Tuggy misunderstands the Aristotelian metaphysics through which he reads the Cappadocians; that he presupposes views about language they reject; that his textual evidence is in some cases circular; and that in other cases it consists of artifacts of English translations that are absent in the Greek, which Tuggy did not consult. According to Radde-Gallwitz, this leads to Tuggy's implausible interpretation of "homoousious" as "same thing," which is not how anybody in the fourth century actually understood that term.

Four papers touch on the divine processions and the issue of subordinationism, among other topics. Mark Edwards ("Is Subordinationism a Heresy?") notes that modern theologians often simply assume that subordinationism in any form is a heresy. If, however, we distinguish different kinds of subordination, it is not clear from scripture or conciliar tradition that every kind of subordination is indeed heretical. The tradition allows that the Son is causally and economically subordinate, but rules out the Son as ontologically subordinate. It does not clearly preclude, though, the Son's being axiologically subordinate (subordinate in rank or status).

In reply to Edwards' paper, R.T. Mullins ("Trinity, Subordination, and Heresy: A Reply to Mark Edwards") considers two arguments for the claim that some conciliar kinds of subordination imply some heretical kinds of subordination, which raises the worry that Conciliar Trinitarianism is incoherent.

Timothy Pawl ("Conciliar Trinitarianism, Divine Identity Claims, and Subordination") considers two questions concerning Conciliar Trinitarianism. 1. What relation does each divine person bear to the divine nature? 2. Do the divine 
processions imply an objectionable kind of subordination? Pawl argues that neither the identity nor instantiation views fit the conciliar texts, and suggests this as a subject calling for further research. He also argues that the divine processions do not create an objectionable subordinationism.

Alexis Torrance ("Defining and Supplementing Conciliar Trinitarianism: A Response to Timothy Pawl") offers three comments in response to Pawl's paper. 1. The conciliar texts are limited as a source for an articulation of trinitarian teaching. 2. As each divine person is not strictly identical to the divine nature, so, Torrance argues, the divine nature is not strictly identical to the divine power, will, or energy. 3. Torrance argues that on the topic of how the Holy Spirit proceeds, Pawl should give more weight to the first council of Constantinople's exposition of faith, which says that the Holy Spirit proceeds from the Father, but does not imply any causal origin of the Spirit from the Son.

Finally, a few papers trace an argument or theme in some theologian(s) central to Conciliar Trinitarianism. Dennis Bray ("Gregory Of Nazianzus' Trinitarian Argument in Oration 23") gives a close reading of Gregory Nazianzen for the claim that the Son and Spirit proceed from God's essence, against the contrary claim made by Eunomius. Bray analyzes Nazianzen's argument as a series of dilemmas concerning the number of divine persons and natures. Each dilemma either has a straight-forwardly embarrassing consequence for Eunomius, or leads to a further dilemma. But although the argument is intended as an attack on Eunomius' theology specifically, it also illuminates Gregory's positive theological position on the necessity of the Father's production of the Son and Spirit.

Giulio Maspero ("La perichoresis e la grammatica teologica dei primi sette Concili ecumenici") traces the history of the term 'perichoresis' from Gregory Nazianzus, who uses the concept to describe the relation between Christ's two natures, through Maximus the Confessor, who applies it to the deification of humans, and finally on to John Damascene, who applies it to the relation between the divine persons. Maspero argues that the concept unifies different areas of theology by rooting them ultimately in the Trinity.

Anna Zhyrkova ("Can We Predicate of and Speak about God, and What Are the Rules for Doing So? On the Epistemological and Logical Premises of Conciliar Trinitarianism") draws our attention to the Stoic philosophical backgrounds regarding logic and epistemology that were at play in the debate between Eunomius and Basil the Great. If, as she argues, Basil and Gregory of Nyssa's understanding of discourse about the Trinity is the key for interpreting Conciliar Trinitarianism, then we are obliged to understand the logical and epistemological commitments that frame our interpretation of conciliar statements about the Trinity. Failing that, we 
are likely to misinterpret statements about the Trinity in Conciliar Trinitarianism. Zhyrkova concludes that if we accept a Cappodocian apophatic stance regarding the divine essence, then this should influence how we interpret what seem to be positive claims about the Trinity in itself - for example, the distinction between what is common (divine essence) and what is not common (divine persons) - as found in Conciliar Trinitarianism.

Richard Cross ("On the Interpretation of Church Councils: A Response to Anna Zhyrkova's Conciliar Trinitarianism") makes some distinctions in order to understand what is at issue in Zhyrkova's article. He distinguishes a material question about the relation between the divine essence and divine attributes, and a formal question about what is common (the divine essence) and what is not common (the divine persons). Next, he distinguishes a thin account that is more apophatic, and a thick account that is more cataphatic. Lastly, Cross questions whether there is one hermeneutical 'key' (as Zhyrkova seems to suggest) to interpret the Ecumenical Councils. Whereas a thin account says there are a plurality ways to interpret conciliar statements, a thick account says there is one correct way. Using these distinctions, he contrasts what he calls Zyhrkova's "thin formalism, thin materialism, and thick conciliar hermeneutics," with what Cross argues was Basil the Great's "thick formalism, thin materialism, and thin conciliar hermeneutics." If Cross is right, then contra Zhyrkova there are some positive metaphysical claims to be found in Conciliar Trinitarianism. 